\title{
SYSTEM OF ORGANIZATIONAL AND ECONOMIC SUPPORT OF HUMAN RESOURCES MANAGEMENT AT ENTERPRISES
}

\author{
VALENTYNA YAKUBIV, ROMAN YAKUBIV
}

\begin{abstract}
The paper analyses various scientific approaches to the interpretation of the essence of the concept of "personnel management", defines the specific characteristics and principles of this process. For a detailed study of the essence and content of the concept of the personnel management, theoretical approaches to this definition and substantiation of its content in the context of various scientific schools and management theories are analysed. Scientific approaches to understanding the functional role and essence of the personnel management in various scientific schools are analysed, namely: schools of scientific management, classical (administrative) school of management, theory of perfect bureaucracy, school of human relations, empirical school of management, school of social systems, and "new school".

The main differences in understanding the process of the personnel management in different theories of management are investigated, the main of which are: situational management theory; system theory of management; theory of organizational culture; theory of human resources management; theory of management culture. The relationship scheme and the place of the personnel management system in the enterprise management in general are substantiated. A threelevel personnel management system for tactical, operational and ongoing tasks is proposed. The mechanism of organizational and economic support of the personnel management as a system of synergistically interconnected organizational and economic factors for establishing highperformance HR-management in the enterprise is substantiated. The main elements of organizational and economic support for improving the personnel management system of enterprises are scientific and theoretical approaches to the forming of this system; principles of personnel management; methods of labour management; functions of HR-management; economic levers; methodological support; information support; monitoring of personnel management.
\end{abstract}

Keywords: renewable energetics, strategic analysis, PEST-analysis, external factors, renewable sources of energy.

\section{INTRODUCTION}

European integration processes taking place in Ukraine presuppose the necessity of In the current conditions of socio-economic relations, the formation of management system plays an important role for entrepreneurship development. Personnel management deserves special attention because human resources are a determining factor in the success of an enterprise's activity. The fastest development of the personnel management system takes place in the financial-credit and IT business, and the most 
slowly - in the agricultural and other industrial sphere. Analyzing the causes of these trends, it becomes clear that innovative methods of personnel management are spreading more quickly in the industries, enterprises or organizations involved in external investment. Therefore, usage of modern management theory becomes more and more frequent in our country. However, given the specifics of the enterprises in Ukraine and slow development of some of them, the personnel management in this field still needs to be im proved.

\section{RESULTS}

Exploring the essence of the concept "management" in various scholars, we conclude that this term is used as a synonym for the definition of "administration". Therefore, these two terms are analyzed together in the paper.

One of the founders of management theory was A. Fayol, who developed a coherent theory of management. According to the scientist, to manage means "to anticipate and study the future and to plan an action program" [1, p. 30].

English scientist S. Bir believes that the management system is the brain center of the enterprise $[2$, p. 5]. Obviously, it is quite difficult to disagree with the scientist, since in fact all the employees of the enterprise are executing the orders of the administration, who is responsible for development.

A well-known successful manager Lee Iacocca, who contributed to the rapid, profitable development of Ford, under management understands the ability to recruit others, motivate them and create a sense of involvement of the employees to solve the problem of organizational development [3, p. 290]. Lee Iacocca links the overall process of enterprise management to personnel management.

J. Gereth and J. George interpret management as the organization, administration, and control of resources for their rational and effective use [4, p. 14].

N. Tarnavska considers the concept "management" as more general, namely, "the most important resource of the enterprise, the ability to produce the purpose of the activity, to measure performance, to fulfill the set functions, to influence people with different level of education, experience, and qualification [5, p. 152].

Similar to Lee Iacocca, management is identified with personnel management by A. Kuzmin and O. Melnyk. In particular, by management they mean "purposeful influence on employees or individual executors aimed at realization of the set tasks" [6, p. 77-83]. This approach is noteworthy because the process of managing enterprise activity, innovation development, and operational activity involves influencing people's behavior.

However, some authors differentiate the essence of the concept of "personnel management". Thus, M. Vinogradsky, S. Belyaeva, A. Vinogradska, and O. Shkanova by this category understand the activity of an organization aimed at the effective use of people (personnel) to achieve the goals, both organization and individual (personal) [7, p. 34-37].

Similar generalized definition is given by G. Bennett, who by the personnel management understands the part of the management process related to the work of employees in the enterprise and the relationships between them [8, p. 12-14].

G. Osovska and O. Osovska give a similar definition to the previous authors, which does not specify the purpose, methods, etc. These authors by the personnel management mean "the impact on the staff for a specific purpose through the necessary interconnected activities" [9, p. 16].

The definitions of the "personnel management" discussed above are rather generalized and do not clearly define the nature of this category. In contrast to the previous interpretations, more complete and thorough one is given by V. Lukianykhin, who under the investigated category understands "the process of systematic, organized, through interdependent organizational-economic and sociopsychological management mechanisms, influence on employees of the organization to ensure the effective functioning of the organization as a whole and to meet the needs of each employee in their professional and personal development" [10, p. 34]. 
Some scholars use the term "personnel management" alongside the term "cadre management". Thus, S. Mochernyi in the economic encyclopedia substantiates that it is a complex of measures of cadre activities, purposeful active influence of executives (personnel managers) of the enterprise (firm, company) by means of interrelated organizational-economic and social measures on increase of production and creative activity of employees and development of perspective personnel policy [11, p. 295].

Generalizing the above interpretations of the "personnel management" by different scholars and considering the lack of a unified approach to its justification, we see it necessary to supplement and clarify such definitions. In our opinion, personnel management as a component of the overall enterprise management system is a process of systematically organized, purposeful influence of managers at different levels on the personnel of the enterprise by ensuring their rational formation, use and reproduction in order to increase the productivity of the business entity.

Our definition differs from the others by the following statements: firstly, personnel management is an integral part of the overall enterprise management system; secondly, it is a process of deliberately influencing of the executives on competitive entities, which implies the existence of clearly defined links between elements of the general system; thirdly, personnel management has a specific purpose increasing the profitability of labor and a more general purpose - to promote the efficiency of the activity as a whole.

For a detailed study of the essence and content of the concept of personnel management, theoretical approaches to this definition and substantiation of its content in various scientific schools and management theories are analyzed.

It is well known that management as a science was developed by American scientists in the 19th century. To date, the following major management schools are known:

- School of Scientific Management (1885-1920);

- Classical (Administrative) School of Management (1920-1950);

- the theory of ideal bureaucracy (since 1920);

- School of Human Relations (since 1930);

- Empirical School of Management (since 1940);

- School of Social Systems (since 1970);

- "New School" (since 1960).

The School of Scientific Management (1885-1920) paid considerable attention to the scientific study of the time and efforts of employees in the production process. The founder of this school was Frederick Taylor, well-known followers were G. Hunt, G. Ford, G. Emerson, L. Gilbert. In the scientific works of representatives of the School of Scientific Management, much attention is paid to leadership theory, principles of personnel management, the organization of work in enterprises.

The Classical or Administrative School of Management (1920-1950) is focused on conducting administrative studies of management effectiveness. The founder of this school was A. Fayol, and his followers were: L. Urvik, J. Mooney, A. Raleigh and others. In their works, scientists have developed the principles and functions of management, formed by A. Fayol.

The School of Ideal Bureaucracy Theory (since 1920) is based on the idea about the bureaucratic structure of society as a determining factor in the development of formal rules of government. The main representative of this theory is Max Weber (1864-1920). The scientific developments of the school's representatives relate to the study of the division of labor, the hierarchy of management, the issues of hiring em ployees, and career advancement.

The School of Human Relations (since 1930) has paid considerable attention to the issues of establishing positive interpersonal relationships between employees and managers. The founder of this school was E. Mayo, and well-known followers were M. Follett, F. Herzberg, D. McGregor, R. Blake. The scientists investigate the problems of work efficiency, staff motivation, team relationships

The Empirical School of Management (since 1940) has explored management in the context of combining the ideas of the classical school and the school of human relations. The founder of the school was P. Drucker, the followers were A. Sloan, R. Davis, A. Chandler, D. Miller. The scientists paid 
attention to strategic goals in the management system, involvement of employees in making strategic decisions and assessing the effectiveness of management.

The School of Social Systems (since 1970) explores organizational and managerial aspects of enterprise activity. The founders were C. Barnard, D. March, and G. Simon. The school introduced the latest approach to management - situational, the application of which avoided the possibility of recurring problematic situations in the organization.

The New School (since 1960) is characterized by the efforts of its representatives to build a system of management based on mathematical sciences. The main representatives of this school are S. Beer, R. Luce, R. Acoff. Scientists apply mathematical, cybernetics, physics laws in management.

Basic world schools of management have formed the complex management theories, the main of which are:

- situational theory of management;

- system theory of management;

- theory of organizational culture;

- theory of human resources management;

- theory of management culture.

Modern scientists, considering the theoretical foundations of the personnel management system, are working on improving their directions taking into account the existing tendencies and peculiarities of human resources development for different countries, industries, enterprises $[12,13,14,15,16]$.

As far as personnel management is one of the important organizational and managerial processes of an enterprise it is not possible to analyze it separately from the general management system of the enterprise (Fig. 1).
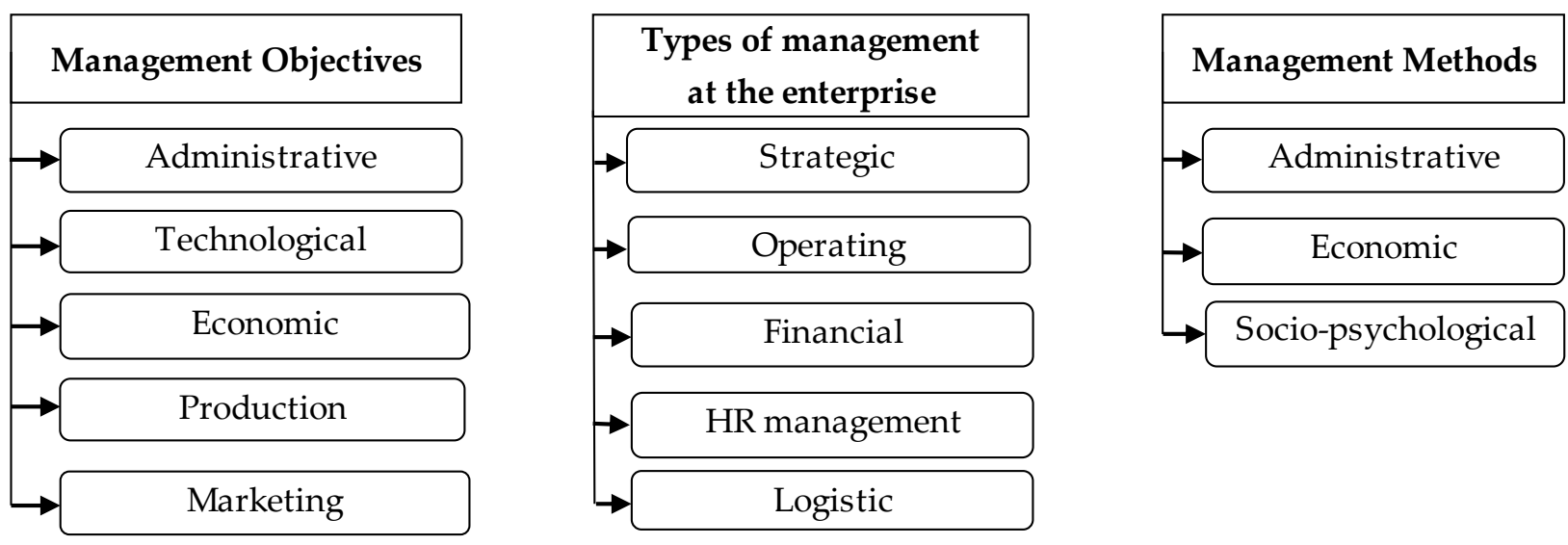

Fig. 1. Personnel management in the enterprise management system

* Source: Developed by the author

All management systems, including personnel management, are multilevel. This is due to the organizational structure of the organization or enterprise. In management theory, various models of organizational structure of management are known. The most famous are American and Japanese models. The American model considers a clear hierarchy in management based on three levels: Level I the highest administrative level, Level II - the middle level executives, and Level III - the lower level executives. Management decisions are made from top to bottom of the hierarchy. A typical Japanese management model also involves three-level management, but with some branching of middle-level executives. At this middle level, there is no clear hierarchy of top-down management decisions, and parallel relationships are observed. The Japanese model is the most mobile and flexible and prevents bureaucracy.

Based on the analysis of the advantages and disadvantages of different management models, as well as taking into account the existing baseline conditions observed at Ukrainian enterprises, we have generalized and proposed to apply a three-level personnel management system (Fig. 2). 


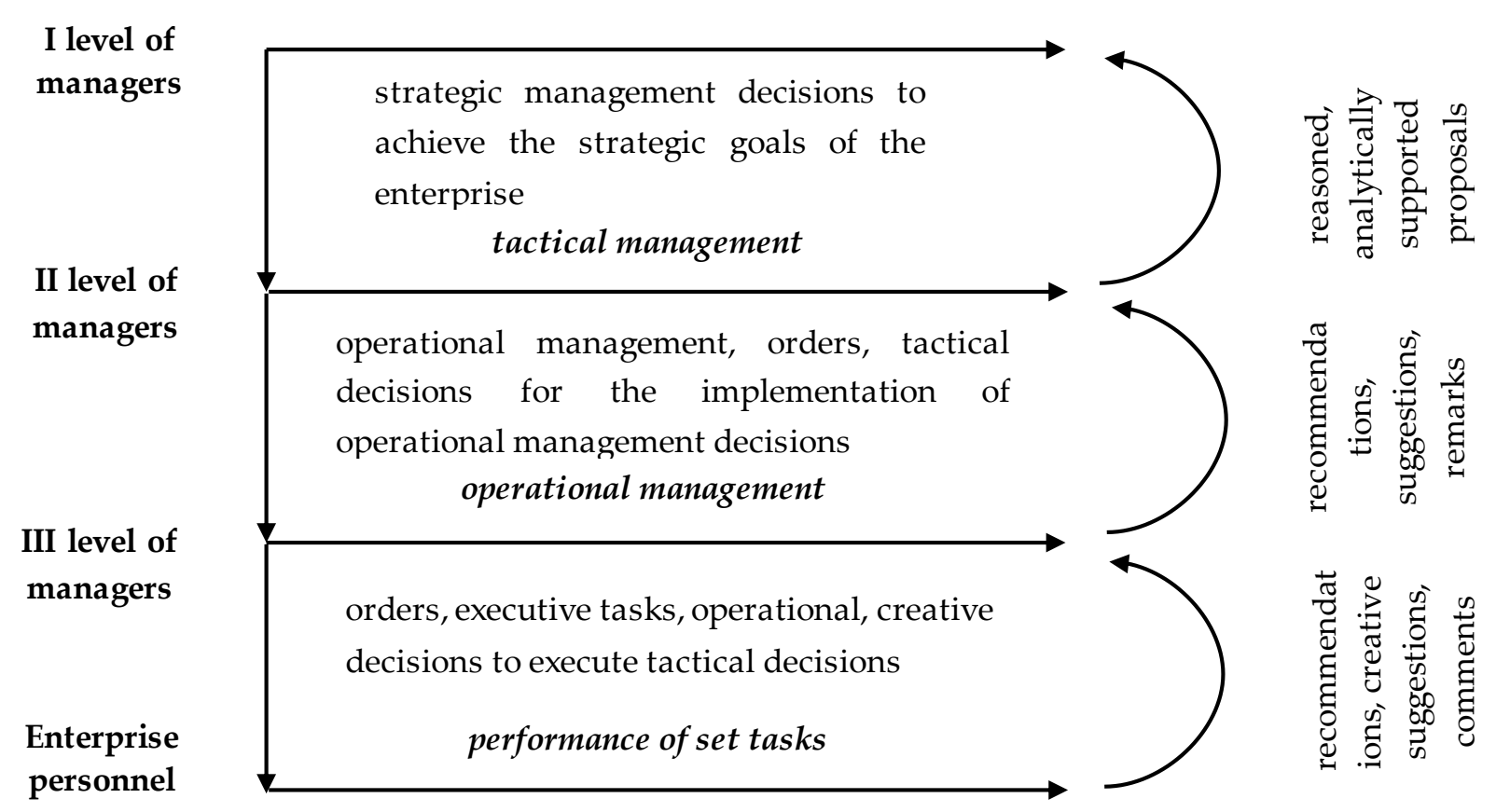

Fig. 2. Multilevel management system of enterprise personnel

* Source: Developed by the author

Fig. 2 shows the organizational structure of personnel management, which implies the influence from the highest - I level to the lowest III level of managers. Accordingly, managers of the I level have the broadest powers in the enterprise and first of all determine the strategy of development of the enterprise and basic ideas of management. The level II executives are responsible for tactical management, that is, they are required, on the basis of a well-grounded development strategy, to determine the directions and actions for their achievement that must be implemented in the short term. The level III executives assign so-called operational management, that is, by executing orders of toplevel managers, they make operational management decisions. These managers are the link between the top-management of the enterprise and its employees.

In the proposed structure of the personnel management system, it is important to have a hierarchy of connections and relationships between managers at different levels, as well as to establish feedback from the enterprise employees to the managers.

In today's market environment, problems of the organization and functioning of the management system are underestimated in terms of their importance and the ability to achieve the expected results. Modern entrepreneurs believe that they have current financial, technical and other production and economic problems, and the issues of improving management aspects are not so important. This is where all the problems of functioning of enterprises begin, because the organization of all the activity of the enterprise depends on the rationality of management decisions. Particularly insufficient attention is paid to personnel management. However, given that the main components of production potential are land, logistical resources and personnel, only the improved management of manpower can increase its efficiency.

Therefore, in the overall management system at the enterprise, the defining element is personnel management. Through the organization of labor management, it is possible to achieve an increase in labor productivity and production efficiency in general, since a person works with all material, technical and land resources, ensuring the organization of the production process and affecting its productivity.

Implementation of an effective personnel management system at enterprises should be preceded by the development of organizational and economic support for this process.

By the organizational and economic support of human resources managem ent we understand the system of synergistically interconnected organizational and economic factors for establishing high- 
performance HR-management in the enterprise. The phenomenon is specific in its applied sense, since the object and the subject is a person. Therefore, in order to achieve this goal, it is necessary to develop and implement a comprehensive organizational and economic support of the personnel management system.

In substantiating such a mechanism of organizational and economic support, principles, approaches, and tools should be taken into account not just as organizational and economic factors, but in their close interaction and complementarity (Fig. 3).

Fig. 1.3 shows that the main elements of organizational and economic support for improving the enterprise personnel management system are:

- scientific and theoretical approaches to the construction of personnel management system;

- principles of personnel management;

- manpower management methods;

- HR management functions;

- economic levers;

- methodological support;

- information support;

- monitoring of personnel management.

The proposed system of organizational and economic support for improving the personnel management of enterprises is based on the generalization of basic scientific approaches and the complement of components related to the peculiarities of the functioning of different enterprises.

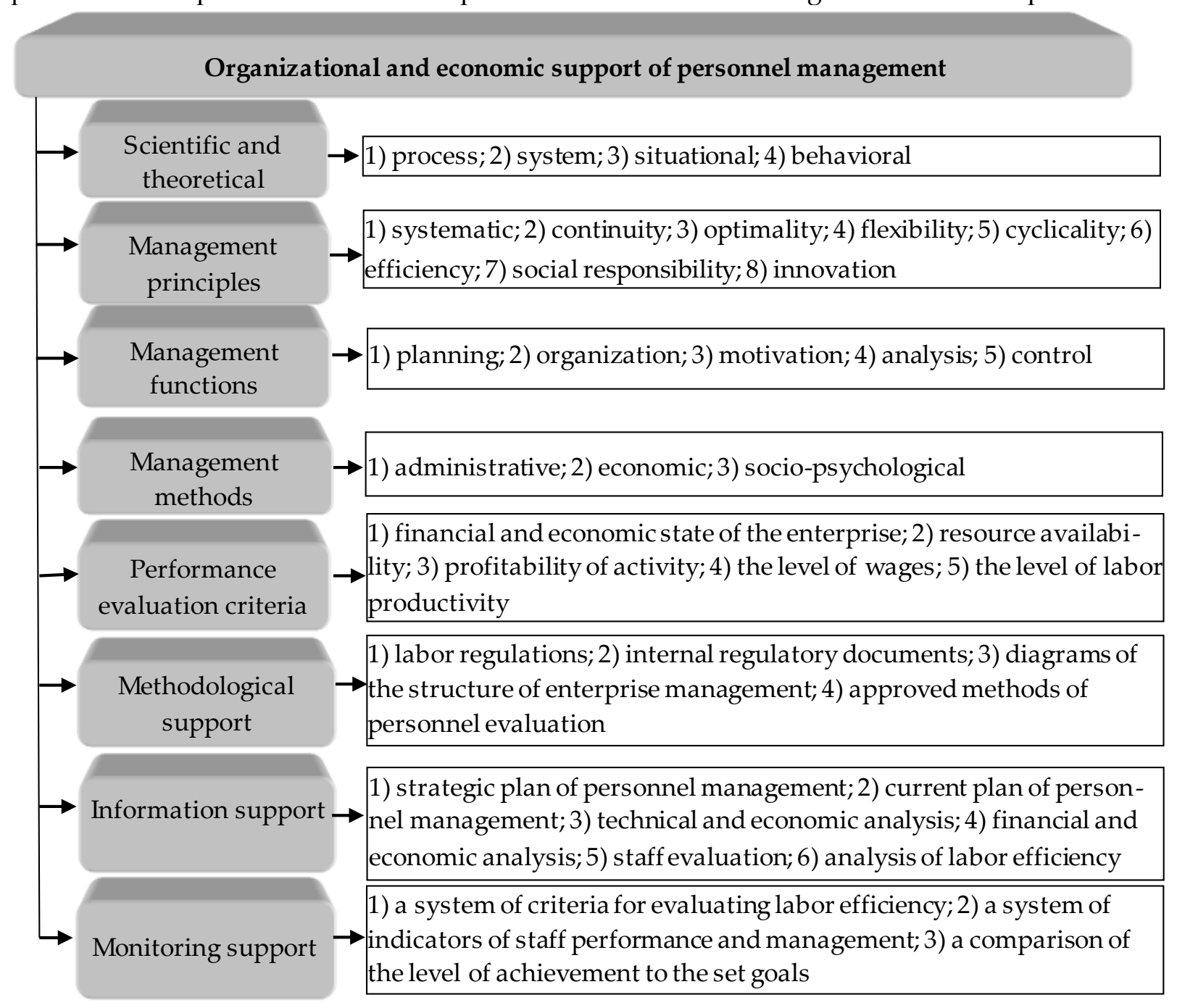

Fig. 3. System of organizational and economic support of personnel management of enterprises * Source: Developed by the author 


\section{CONCLUSIONS}

The analysis of different scientific approaches to understanding the essence and functional purpose enables to substantiate the role and place of personnel management in the system of enterprise development, as well as to classify its levels. In order to identify promising areas of the personnel management at the enterprises, an organizational and economic mechanism of improvement of the human resource management system is proposed, which includes scientific and practical approaches, principles, functions, methods of personnel management, evaluation criteria, methodological support, information and monitoring support.

\section{REFERENCES}

[1] Murashko M.I. Personnel management: training-practice book. Znannya, Kyiv, 2002. (in Ukrainian)

[2] Bir S. Company Brain: Trans. from English. Radio i svyaz', Moscow, 1993. (in Russian)

[3] Zavadsky J.S. Management: in 2 volumes. Vid-vo Yevrop. un-tu, Kyiv, 2003. (in Ukrainian)

[4] Jones G.R., George J.M. Contemporary management. McGraw-Hill Irwin, 2006.

[5] Tarnavska N.P. Enterprise competitiveness management: theory, methodology, practice. Ekonomichna dumka ternopil, Ternopil, 2008. (in Ukrainian)

[6] Kuzmin O.Ye., Melnyk O.G. Fundamentals of Management. Akademvydav, Kyiv, 2007. (in Ukrainian)

[7] Vinogradsky M.D., Vinogradska A.M., Shkanova O.M. Managing Staff. Center of Educational Literature, Kyiv, 2009. (in Ukrainian)

[8] Graham H.T., Bennett R. Human resources. Management. Longman Group UK Ltd, London, 1995.

[9] Osovska H.V., Osovskyi O.A. Fundamentals of Management. Kondor, Kyiv, 2006. (in Ukrainian)

[10] Lukianykhin V.O. Staff Management: A Training Manual. VTD „Universytetska knyha”, Sumy, 2004. (in Ukrainian)

[11] Mocherny S.V. (Ed.) Economic Encyclopedia: In three volumes. Vol.2. Vydavnychyi tsentr "Akademiia", Kyiv, 2001. (in Ukrainian)

[12] Adizes I. The ideal executive: Why You Cannot Be One and What To Do About It A New Paradigm for Management. Adizes Inst, Santa Barbara, 2004.

[13] Ian Mann. Reviews: Bedtime stories for managers. Available at: https://www.fin24.com/Opinion/ianmann-reviews-bedtime-stories-for-managers-20191014

[14] Yakubiv V.M., Horohotska N.I., Yakubiv R.D. Administrative model of ensuring the development of agricultural enterprises through diversification processes implementation. Actual Problems of Economics, 8 (2015), 58-65. (in Ukrainian)

[15] Yakubiv V., Poliuk M. Innovative methodologies for estimating the personnel of agricultural enterprises in Ukraine. Scientific Papers Series Management, Economic Engineering in Agriculture and Rural Development, 19(1) (2019), 617-624. Available at: http://managementjournal. usamv.ro/pdf/vol.19_1/volume_19_1_2019.pdf

[16] Yakubiv V.M. Conceptual principles of the strategy of balanced development of agricultural enterprises. Ekonomika APK "The Economy of Agro-Industrial Complex", 4 (2011), 104-107. (in Ukrainian)

Address: Valentyna Yakubiv, Roman Yakubiv, Vasyl Stefanyk Precarpathian National University, 57, Shevchenko Str., Ivano-Frankivsk, 76018, Ukraine.

E-mail: yakubiv.valentyna@gmail.com, roman.yakubiv@gmail.com

Received: 20.08.2019; revised: 27.11.2019. 
Якубів Валентина, Якубів Роман. Організаційно-економічний механізм управління персоналом на підприємствах. Журнал Прикарпатського університету імені Василя Стефаника, 6 (3-4) (2019), 88-95.

У статті проаналізовано різні наукові підходи до тлумачення сутності поняття “управління персоналом", визначено специфічні характеристики та принципи цього процесу. Для детального дослідження сутності і змісту поняття менеджменту персоналу проаналізовано теоретичні підходи до даної дефініції і обгрунтування іiі змісту в розрізі різних наукових шкіл і теорій управління. Проаналізовано наукові підходи до розуміння функціональної ролі та суті управління персоналом у різних наукових школах, а саме: школі наукового управління, класичній (адміністративній) школі управління, теорії ідеальної бюрократії, школі дюдських стосунків, емпіричній школі управління, школі соціальних систем, “новій школі". Досліджено сутнісні відмінності щодо розуміння процесу управління персоналом у різних теоріях менеджменту, основними 3 яких є: ситуаційна теорія менеджменту; системна теорія менеджменту; теорія організаційної культури; теорія менеджменту людських ресурсів; теорія культури управління. Обгрунтовано схему взаємозв' язків та місця системи менеджменту персоналу в управлінні підприємством загалом. Запропоновано трирівневу систему менеджменту персоналу на тактичному, оперативному та виконання поточних завдань. Обгрунтовано механізм організаційно-економічного забезпечення управління персоналом як систему синергійно взаємопов'язаних організаційних та економічних забезпечуючих факторів для налагодження високорезультативного HR-менеджменту на підприемстві. Основними елементами організаційноекономічного забезпечення удосконалення системи управління персоналом підприємств є: науково теоретичні підходи до побудови системи управдіння персонадом; принципи менеджменту персоналу; методи управління трудовими ресурсами; функції HR-менеджменту; економічні важелі; методичне забезпечення; інформаційне забезпечення; моніторингове забезпечення управління персоналом.

Ключові слова: управління персоналом, менеджмент, організаційно-економічний механізм, теорії менеджменту, управління підприємством. 